\title{
Leukotriene Inhibition Prevents and Reverses Hypoxic Pulmonary Vasoconstriction in Newborn Lambs
}

\author{
MICHAEL D. SCHREIBER, MICHAEL A. HEYMANN, AND SCOTT J. SOIFER \\ The Cardiovascular Research Institute and the Departments of Pediatrics, Physiology, and Obstetrics, \\ Gynecology, and Reproductive Sciences, University of California, San Francisco, California 94143
}

\begin{abstract}
The effects of the leukotriene antagonist FPL 57231 on the circulation were studied in spontaneously breathing normoxic and hypoxic newborn lambs in order to evaluate the role of leukotrienes in the perinatal control of hypoxic pulmonary vasoconstriction. Hypoxia produced a $58 \%$ increase in pulmonary arterial pressure $(p<0.05)$ and a $37 \%$ increase in pulmonary vascular resistance $(p<0.05)$. Hypoxic pulmonary vasoconstriction was abolished by the prior infusion of FPL 57231. Pulmonary arterial pressure increased by only $8 \%$ and pulmonary vascular resistance decreased by $10 \%$ from normoxia. The infusion of FPL 57231 during hypoxia-induced pulmonary vasoconstriction reversed the increase in pulmonary arterial pressure $(p<0.05)$ and pulmonary vascular resistance $(p<0.05)$. The hypoxia-induced increase in cardiac output was maintained during the infusion of FPL 57231. Leukotrienes may play a significant role in the mediation of hypoxic pulmonary vasoconstriction. Leukotriene inhibition with FPL $\mathbf{5 7 2 3 1}$ may be useful in the management of infants with persistent pulmonary hypertension syndrome. (Pediatr Res 19: 437-441, 1985)
\end{abstract}

\section{Abbreviations}

PPHN, persistent pulmonary hypertension of the newborn PG, prostaglandin

PG1 2 , prostacyclin

The exact mechanisms by which hypoxia produces pulmonary vasoconstriction remain unknown. The production and release of the noncyclooxygenase products of arachidonic acid from the lung may play an important role. Leukotrienes, the 5 '-lipoxygenase metabolites of arachidonic acid, are produced by mast cells $(1,2)$, alveolar macrophages $(3)$, and pulmonary vascular tissue (4-6). Leukotrienes induce smooth muscle contraction in a variety of tissues (7-10). Leukotriene D4 infused into the pulmonary artery of young lambs produces pulmonary arterial hypertension (11). Leukotriene inhibition with FPL 57231 (Fisons, plc, Loughborough, UK), a leukotriene receptor antagonist (12), significantly increases pulmonary blood flow and decreases pulmonary vascular resistance in fetal lambs (13). Leukotrienes

Received October 9, 1984; accepted December 27, 1984.

Requests for reprints should be addressed to Dr. Scott J. Soifer, Cardiovascular Research Institute M-342A, University of California, San Francisco, CA 94143.

Supported in part by grants from the American Lung Association and U.S. Public Health Service Program Project Grant HL 24056. M.D.S. is recipient of the American Heart Association, California affiliate fellowship award. S.J.S. is recipient of New Investigator Award HL 29941 from the NHLBI. have been isolated from the lung lavage fluid of newborn infants with persistent pulmonary hypertension syndrome but not from newborn infants with other lung diseases (14). These findings suggest that leukotrienes may play a role in maintaining the elevated pulmonary vascular tone in the normal fetus in utero and also in the mediation of hypoxic pulmonary vasoconstriction after birth. The effects of the leukotriene antagonist FPL 57231 on the circulation were therefore studied in normoxic and hypoxic spontaneously breathing newborn lambs.

\section{METHODS}

Surgical procedure and drug preparation. Six mixed-breed newborn lambs from 3-7 days old were operated on under local anesthesia with $1 \%$ lidocaine hydrochloride. Polyvinyl catheters were placed in both hind limb arteries and veins and advanced to the descending aorta and inferior vena cava, respectively. A no. 5 French flow-directed thermodilution catheter, with the proximal injection port $15 \mathrm{~cm}$ from the tip, was introduced into the jugular vein and advanced into the pulmonary artery for measuring pulmonary arterial and pulmonary arterial wedge pressures. Right atrial pressure was measured through the proximal port. Cardiac output was determined by the thermodilution technique and calculated by computer (Electro-Catheter model 5000 , Electro-Catheter Corp., Rahway, NJ). Three milliliters of iced-saline was injected into the proximal port for each measurement. Each cardiac output value was taken as the average of three determinations. Following surgery, the lambs were placed in a sling under a radiant warmer to maintain body temperature. An intravenous infusion of dextrose in water was started. Two hours were allowed for recovery.

FPL 57231 was prepared immediately before each experiment as a $1 \%$ solution in sterile water.

Experimental Protocol. FPL 57231 infusion prior to the onset of hypoxia. Following the recovery period, baseline vascular pressures, cardiac output, and arterial blood gas measurements were made in room air (NORMOXIA). Normocarbic hypoxia was then induced by placing a loosely fitting bag over the lamb's head and adding nitrogen with $5 \% \mathrm{CO}_{2}$ to the gas mixture. The $\mathrm{FIO}_{2}$ was varied to produce a $\mathrm{PaO}_{2}$ of $30-40 \mathrm{~mm} \mathrm{Hg}$ in each animal. Measurements were made after 10 min of hypoxia and stable pulmonary hypertension (HYPOXIA). The lamb was returned to room air.

After the lambs resumed baseline values (NORMOXIA), an intravenous infusion of FPL $57231\left(1 \mathrm{mg} \cdot \mathrm{kg}^{-1} \cdot \mathrm{min}^{-1}\right)$ for 20 min was started. Measurements were made after 10 min of the infusion (NORMOXIA + FPL 57231). Hypoxia was then induced as the drug infusion continued, and measurements were made after another 10 min (HYPOXIA + FPL 57231). The infusion was stopped as hypoxia continued, and measurements 
were made after $15 \mathrm{~min}$. The lambs were returned to room air. Measurements were also made with an equivalent infusion of sterile water vehicle during normoxia and hypoxia.

FPL 57231 infusion started during hypoxia. Six to $24 \mathrm{hr}$ were allowed for recovery from the above experiment. In five lambs baseline measurements were made in room air (NORMOXIA). Normocarbic hypoxia was again induced producing hypoxemia $\left(\mathrm{PaO}_{2} 30-40 \mathrm{~mm} \mathrm{Hg}\right)$ and stable pulmonary hypertension. After $10 \mathrm{~min}$, measurements were repeated (HYPOXIA). Hypoxia was continued and an infusion of FPL $57231\left(2 \mathrm{mg} \cdot \mathrm{kg}^{-1} \cdot \mathrm{min}^{-1}\right)$ was started. Measurements were made after $10 \mathrm{~min}$ (HYPOXIA + FPL 57231). The drug infusion was then stopped, and the lambs were returned to room air.

Measurements and calculations. Pulmonary and systemic arterial and right atrial pressures were measured with Statham P23 $\mathrm{Db}$ pressure transducers and recorded continuously on a Beckman multichannel direct-writing recorder. Mean pressures were obtained by electrical integration. Heart rate was measured with a cardiotachometer triggered from the systemic arterial pressure. Cardiac output, pulmonary arterial wedge pressure, and systemic arterial blood gases were measured during all normoxia and hypoxia periods after a steady-state had been reached. The absence of intracardiac shunting was determined by indicator dilution technique. The validity of the thermodilution method has been reported previously $(15,16)$. Pulmonary vascular resistance was calculated as the mean pulmonary arterial pressure minus mean pulmonary arterial wedge pressure divided by cardiac output per kilogram. Systemic vascular resistance was calculated as the mean systemic arterial pressure minus mean right atrial pressure divided by cardiac output per kilogram.

The mean $\pm \mathrm{SD}$ was computed for the vascular pressures, resistances, cardiac output, heart rate, and arterial blood gases during all normoxic and hypoxic conditions. The differences in these variables were compared by two-way analysis of variance and the Newman-Keuls test for multiple comparisons (17). A $p$ $<0.05$ was considered statistically significant.

\section{RESULTS}

FPL 57231 infusion prior to the onset of hypoxia (Table 1, Fig. 1). Normocarbic hypoxia (HYPOXIA) produced a $58 \%$ increase in pulmonary arterial pressure from $18.1 \pm 2.7$ to 28.6 $\pm 3.2 \mathrm{~mm} \mathrm{Hg}(p<0.05)$ and a $37 \%$ increase in pulmonary vascular resistance from $44.0 \pm 6.6$ to $60.4 \pm 6.8 \mathrm{~mm} \mathrm{Hg} \cdot \mathrm{l}^{-1}$. $\mathrm{min}^{-1} \cdot \mathrm{kg}^{-1}(p<0.05)$ compared to normoxia. Systemic arterial pressure was unchanged. Systemic vascular resistance decreased by $16 \%$ during HYPOXIA $(p<0.05)$, as cardiac output increased by $19 \%$.

Infusing FPL 57231 during normoxia (NORMOXIA + FPL 57231 ) produced no significant changes in the hemodynamic variables or arterial blood gases compared to NORMOXIA. Hypoxic pulmonary vasoconstriction was prevented by the prior infusion of FPL 57231 (HYPOXIA + FPL 57231). Pulmonary arterial pressure increased by only $8 \%$ and pulmonary vascular resistance decreased by $10 \%$ compared to NORMOXIA. Pulmonary arterial pressure and pulmonary vascular resistance during HYPOXIA + FPL 57231 were significantly lower than during HYPOXIA $(p<0.05)$. There were no significant changes in systemic arterial pressure and systemic vascular resistance compared to HYPOXIA. The $24 \%$ increase in cardiac output during
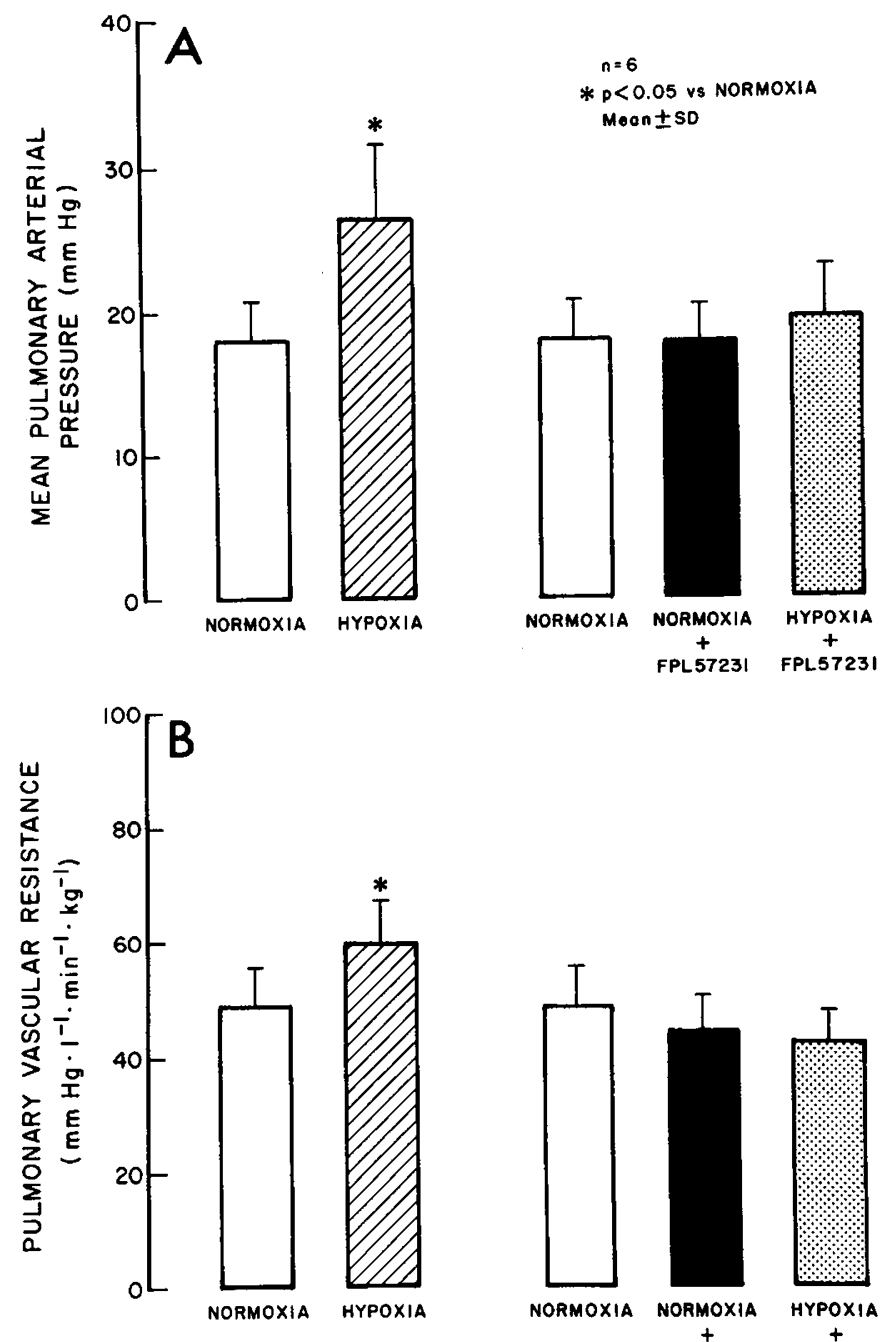

$\stackrel{+}{\text { FPL57231 }} \stackrel{+}{\text { FPL } 57231}$

Fig. 1. The effects of an infusion of FPL 57231 prior to the onset of hypoxia on $(A)$ pulmonary arterial pressure and $(B)$ pulmonary vascular resistance.

Table 1. Effect of FPL 57231 infusion prior to hypoxia (mean \pm SD)

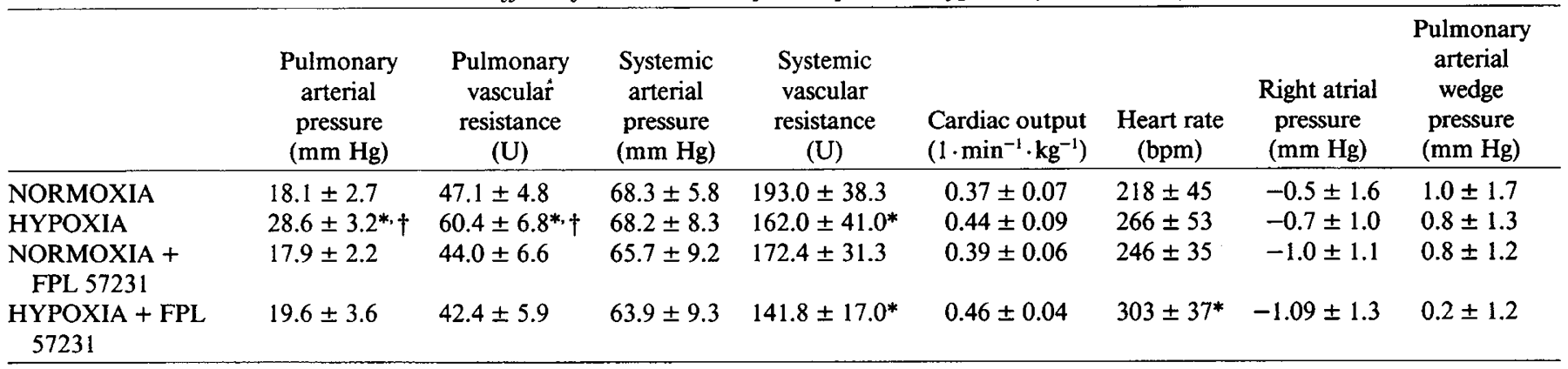

$* p<0.05$ vs NORMOXIA.

$\dagger p<0.05$ vs HYPOXIA + FPL 57231.

$n=6$; units: $\mathrm{mm} \mathrm{Hg} \cdot \mathrm{l}^{-1} \cdot \mathrm{min}^{-1} \cdot \mathrm{kg}^{-1}$. 
HYPOXIA + FPL 57231 compared to NORMOXIA was similar to that during HYPOXIA.

During continued hypoxia, 15 min after the FPL 57231 infusion was stopped, pulmonary arterial pressure had increased significantly by $44 \%$ to $28.2 \pm 4.4 \mathrm{~mm} \mathrm{Hg}(p<0.05)$ and pulmonary vascular resistance had increased $36 \%$ to $57.8 \pm 3.8$ $\mathrm{mm} \mathrm{Hg} \cdot 1^{-1} \cdot \mathrm{min}^{-1} \cdot \mathrm{kg}^{-1}(p<0.05)$. These values were not significantly different from HYPOXIA. Right atrial and pulmonary arterial wedge pressures, heart rate (Table 1), $\mathrm{pH}$, and $\mathrm{PCO}_{2}$ (Table 2) did not change throughout the study. $\mathrm{PaO}_{2}$ and arterial saturation were unchanged during normoxic as well as during hypoxic conditions (Table 2). Infusion of vehicle did not affect the hemodynamic variables or arterial blood gases during either normoxia or hypoxia.

FPL 57231 infusion started during hypoxia (Table 3, Fig. 2). The hemodynamic variables, arterial blood gases, and the response to hypoxia were similar to the above experiment. During hypoxia-induced pulmonary arterial hypertension, infusing FPL 57231 (HYPOXIA + FPL 57231) decreased pulmonary arterial pressure by $35 \%(p<0.05)$ and pulmonary vascular resistance by $37 \%(p<0.05)$ from HYPOXIA. There were small, but not statistically significant, decreases in systemic arterial pressure and systemic vascular resistance from HYPOXIA. The $13 \%$ increase in cardiac output induced by hypoxia was not lowered by the infusion of FPL 57231. Right atrial and pulmonary arterial wedge pressures, $\mathrm{pH}$, and $\mathrm{PCO}_{2}$ were unchanged. $\mathrm{PaO}_{2}$ and arterial saturation were similar during both hypoxic conditions. Whether the infusion of FPL 57231 was started prior to or during hypoxia, pulmonary arterial pressure and pulmonary vascular resistance were similarly affected.

\section{DISCUSSION}

The results of this study indicate that an infusion of FPL 57231 , a competitive leukotriene receptor antagonist (12), prevents pulmonary vasoconstriction with hypoxia and reverses hypoxia-induced pulmonary hypertension in the newborn lamb. There is no attenuation of the hypoxia-induced increase in cardiac output. Systemic arterial pressure decreased slightly. Whether these effects are caused by leukotriene antagonism or inhibition or activation of other substances, or are direct vascular

Table 2. Arterial blood gas analysis when FPL 57231 was infused prior to hypoxia (mean $\pm S D)$

\begin{tabular}{|c|c|c|c|c|}
\hline & $\mathrm{pH}$ & $\begin{array}{c}\mathrm{PO}_{2} \\
(\mathrm{~mm} \mathrm{Hg})\end{array}$ & $\begin{array}{c}\mathrm{PCO}_{2} \\
(\mathrm{~mm} \mathrm{Hg})\end{array}$ & $\begin{array}{c}\text { Arterial sat } \\
(\%)\end{array}$ \\
\hline NORMOXIA & $7.39 \pm 0.04$ & $82.8 \pm 10.7$ & $38.8 \pm 4.1$ & $95.3 \pm 3.0$ \\
\hline HYPOXIA & $7.37 \pm 0.06$ & $32.2 \pm 4.1^{*}$ & $38.7 \pm 3.2$ & $54.2 \pm 15.3^{*}$ \\
\hline $\begin{array}{l}\text { NORMOXIA + } \\
\text { FPL } 57231\end{array}$ & $7.40 \pm 0.05$ & $86.7 \pm 10.3$ & $39.2 \pm 3.2$ & $96.3 \pm 2.9$ \\
\hline $\begin{array}{l}\text { HYPOXIA + } \\
\text { FPL 57231 }\end{array}$ & $7.41 \pm 0.04$ & $34.7 \pm 5.3^{*}$ & $38.2 \pm 2.5$ & $61.3 \pm 17.0^{*}$ \\
\hline
\end{tabular}

$* p<0.05$ vs NORMOXIA.

$n=6$. effects of the compound is not yet known. When infused during normoxia, FPL 57231 produces no significant hemodynamic changes.

Pulmonary vascular tone is maintained through the apparent balance between vasodilating and vasoconstricting substances (18). Various stimuli, including hypoxia, that increase pulmonary vascular resistance may alter this balance by either increasing or decreasing these substances. Many cells, including mast cells, pulmonary macrophages, and vascular tissue, in the lung can metabolize arachidonic acid via the lipoxygenase pathway to leukotrienes, formerly known as the slow-reacting substance
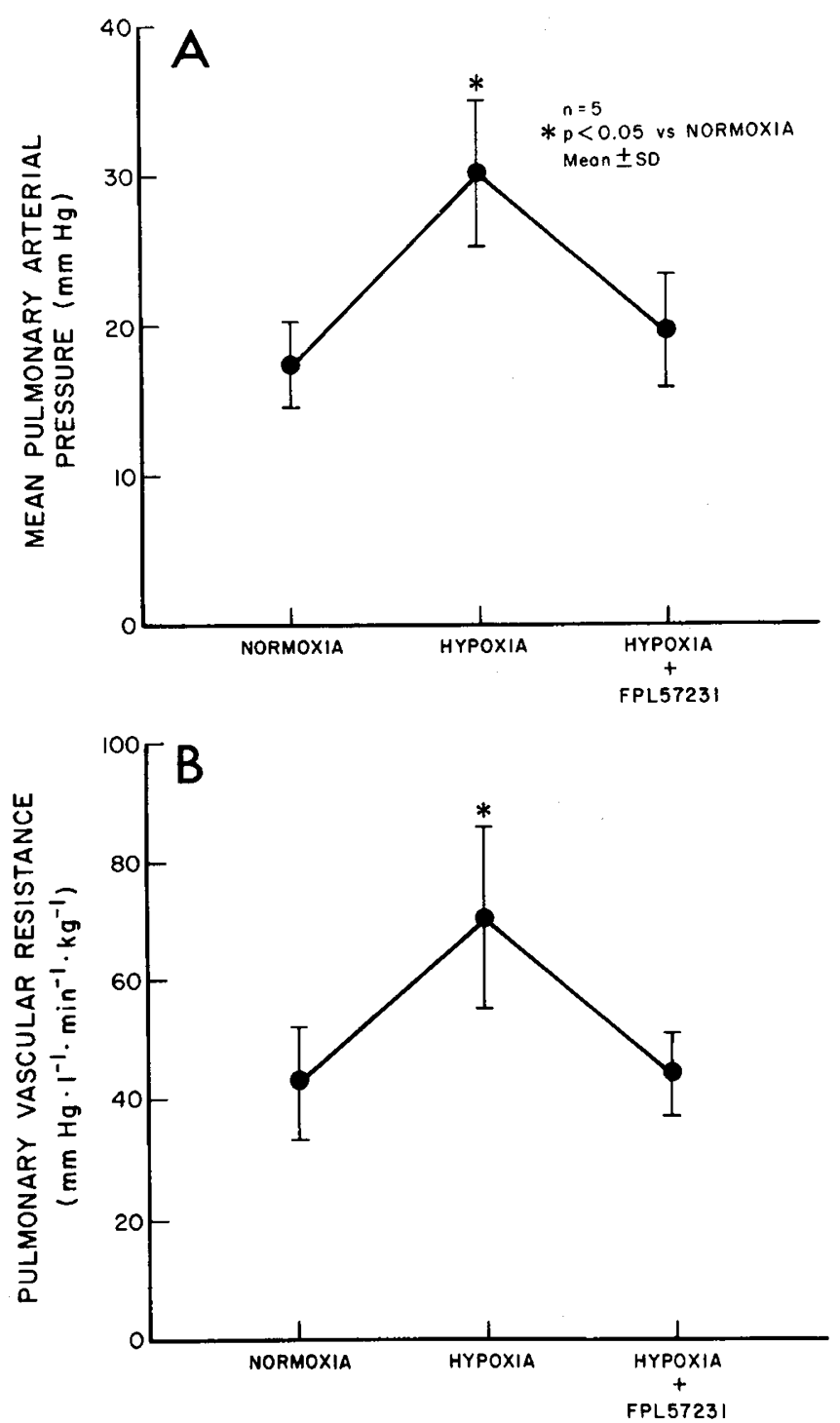

Fig. 2. The effects of an infusion of FPL 57231 during hypoxia on $(A)$ pulmonary arterial pressure and $(B)$ pulmonary vascular resistance.

Table 3. Effect of FPL 57231 infused after hypoxia (mean $\pm S D$ )

\begin{tabular}{lccccc}
\hline & $\begin{array}{c}\text { Pulmonary } \\
\text { arterial } \\
\text { pressure } \\
(\mathrm{mm} \mathrm{Hg})\end{array}$ & $\begin{array}{c}\text { Pulmonary } \\
\text { vascular } \\
\text { resistance } \\
(\mathrm{U})\end{array}$ & $\begin{array}{c}\text { Systemic } \\
\text { arterial } \\
\text { pressure } \\
(\mathrm{mm} \mathrm{Hg})\end{array}$ & $\begin{array}{c}\text { Systemic } \\
\text { vascular } \\
\text { resistance } \\
(\mathrm{U})\end{array}$ & $\begin{array}{c}\text { Cardiac output } \\
\left(1 \cdot \mathrm{min}^{-1} \cdot \mathrm{kg}^{-1}\right)\end{array}$ \\
\hline NORMOXIA & $17.5 \pm 2.9$ & $43.1 \pm 8.8$ & $68.5 \pm 10.5$ & $182.0 \pm 58.2$ & $0.40 \pm 0.08$ \\
HYPOXIA & $30.3 \pm 4.7^{*, \dagger}$ & $70.3 \pm 15.5^{*} \dagger$ & $71.0 \pm 12.4$ & $174.0 \pm 64.4$ & $0.45 \pm 0.11$ \\
HYPOXIA + FPL 57231 & $19.8 \pm 3.6$ & $44.0 \pm 7.0$ & $64.5 \pm 11.1$ & $150.4 \pm 42.1$ & $0.45 \pm 0.08$ \\
\hline
\end{tabular}

\footnotetext{
$* p<0.05$ vs NORMOXIA.

$\uparrow p<0.05$ vs HYPOXIA + FPL 57231.

$n=5$; units: $\mathrm{mm} \mathrm{Hg} \cdot 1^{-1} \cdot \mathrm{min}^{-1} \cdot \mathrm{kg}^{-1}$.
} 
of anaphylaxis, and/or via the cyclooxygenase pathway to prostaglandins $(2-6,19,20)$. $\mathrm{PGI}_{2}, \mathrm{PGD}_{2}$, and $\mathrm{PGE}_{2}$ are pulmonary vasodilators in fetal and newborn animals $(21,22)$. Interestingly, $\mathrm{PGD}_{2}$ is a pulmonary vasoconstrictor in older animals (22). $\mathrm{PGF}_{2}$ is a pulmonary vasoconstrictor in fetal and newborn animals (21). The effects of thromboxanes, potent smooth muscle constrictors, on the perinatal pulmonary circulation are not known. Thromboxane levels are elevated, however, during pulmonary hypertension associated with endotoxin infusion in newborn lambs (23). LTC4 and LTD4 are not only potent pulmonary vasoconstrictors but also stimulate the synthesis of thromboxane and other prostaglandins (24-27). This leukotriene-induced synthesis of thromboxane and other prostaglandins can be blocked by both indomethacin, a cyclooxygenase inhibitor $(26,27)$, and FPL $55712(25,28)$, indicating an interrelationship between the leukotriene and prostaglandin synthetic pathways.

FPL 55712, the parent compound of FPL 57231, is one of a series of chromone-2-carboxylic acids (12). FPL 55712 has been shown to inhibit leukotriene constrictor activity in many tissues including pulmonary vascular, lung parenchymal, and tracheal strips in guinea pig and man (8-10,12). FPL 55712 has other in vitro effects. In concentrations greater than $1.0 \times 10^{-6} \mathrm{M}$, FPL 55712 inhibits thromboxane production from human platelet microsomes (28). It also prevents anaphylaxis-induced thromboxane, $\mathrm{PGI}_{2}$, and $\mathrm{PGE}_{2}$ production and release from guinea pig lung $(19,25,26)$. $\mathrm{PGD}_{2}$ production, however, is not inhibited (19). Whether these effects occur in vivo is not known.

In the intact animal, FPL 55712 inhibits the coronary artery vasoconstriction and improves the myocardial contractility impairment produced by the intracoronary injection of LTD4 into sheep (29). FPL 55712 also increases pulmonary blood flow and decreases pulmonary vascular resistance in late gestation fetal lambs (30).

FPL 57231, the compound used in this study, is a proprionic acid analog of FPL 55712 . FPL 57231 produces a similar degree of leukotriene antagonism with less antiallergic effects (12). Both compounds are rapidly cleared from the plasma, with a serum half-life of $<10 \mathrm{~min}$, and have a similar duration of action (12). In adult sheep, FPL 57231 attenuates hypoxic pulmonary vasoconstriction (7). In near term fetal lambs, intrapulmonary infusions of FPL 57231 markedly increase pulmonary blood flow and decrease pulmonary vascular resistance (13). In preliminary studies in four newborn lambs, FPL 57231 ( $1 \mathrm{mg} / \mathrm{kg} / \mathrm{min})$ completely blocked the hemodynamic effects of intravenously injected LTD4.

Leukotriene receptor stimulation may produce direct cardiovascular changes and induce thromboxane and PG synthesis (24-27, 31). These formed substances may add to the overall hemodynamic effects. FPL 55712 blocks both the direct leukotriene effects and the effects produced by $\mathrm{PG}$ and thromboxane synthesis $(7-9,26,28)$. FPL 57231 also blocks the direct effects of leukotriene (12) but its effect on PG production is not known. In newborn lambs, the intrapulmonary injection of $1 \mu \mathrm{g} \cdot \mathrm{kg}^{-1}$ of LTD4 increases pulmonary vascular resistance by more than $300 \%$. There is also a biphasic effect on the systemic circulation with an initial fall in systemic vascular resistance followed by a $200 \%$ increase. Pretreatment with indomethacin partially blunts the increase in pulmonary vascular resistance and abolishes the initial decrease in systemic vascular resistance (11). In adult sheep, FPL 57231 but not indomethacin blocks hypoxia-induced pulmonary hypertension, while both alter the pulmonary vascular response to infused LTD4 $(7,32)$. This interaction between leukotrienes and PG may be important in controlling the pulmonary circulation.

Leukotriene antagonism through both receptor blockade with FPL 55712 and synthesis inhibition with diethylcarbamazine citrate attenuates hypoxic pulmonary vasoconstriction in isolated perfused rat lungs (33). The results of this and the above studies $(7,33)$ indicate a role for leukotrienes in the mediation of hypoxic pulmonary vasoconstriction. Similarly, FPL 55712 blocks exog- enous LTC4-induced pulmonary vasoconstriction, with no effect on angiotension II-induced vasoconstriction (33). These results suggest a specific capacity for leukotriene antagonists to block leukotriene-mediated vasoconstriction.

Although FPL 57231 prevented and reversed hypoxic pulmonary vasoconstriction in this study, it had little effect on other hemodynamic variables during hypoxia. Cardiac output is either increased, decreased, or unchanged during hypoxia (18). The hypoxia-induced increase in both cardiac output and heart rate observed in this study were maintained during the infusion of FPL 57231. These results would suggest that the mechanism of the hypoxia-induced increase in pulmonary arterial pressure is different from that which induces the change in cardiac output. The former mechanism is possibly mediated through leukotrienes, the latter possibly through autonomic pathways.

Various doses of FPL 57231 were infused prior to the onset of hypoxia to determine the lowest dose that would prevent hypoxic pulmonary vasoconstriction: $1-2 \mathrm{mg} \cdot \mathrm{kg}^{-1} \cdot \mathrm{min}^{-1}$ of FPL 57231 completely inhibited the hypoxia-induced increase in pulmonary arterial pressure and pulmonary vascular resistance; $0.5 \mathrm{mg}$. $\mathrm{kg}^{-1} \cdot \mathrm{min}^{-1}$ was less effective in preventing hypoxic pulmonary vasoconstriction. The effect of exogenous LTD4 in adult sheep can be inhibited by $0.66 \mathrm{mg} \cdot \mathrm{kg}^{-1} \cdot \mathrm{min}^{-1}$ of FPL 57231 (32). Therefore, we used a $1 \mathrm{mg} \cdot \mathrm{kg}^{-1} \cdot \mathrm{min}^{-1}$ infusion during the preinfusion study. To reverse pulmonary hypertension induced by hypoxia, $2 \mathrm{mg} \cdot \mathrm{kg}^{-1} \cdot \mathrm{min}^{-1}$ was used because higher doses of FPL 57231 may be necessary to block existing pulmonary vasoconstriction. This dose of FPL 57231 reverses hypoxic pulmonary vasoconstriction in adult sheep (7).

In the clinical syndrome of PPHN, pulmonary vascular resistance does not fall normally with the initiation of respiration. Pulmonary hypertension is seen in a variety of clinical situations, including meconium aspiration, sepsis, and hyaline membrane disease $(34,35)$. There may be a common pathway mediating syndromes that produce pulmonary hypertension. Leukotrienes have been isolated in lung lavage fluids from infants with PPHN, but not in others with pulmonary disease without pulmonary hypertension (14), suggesting a role for leukotrienes in the pathogenesis of PPHN. Despite the use of supplemental oxygen, mechanical hyperventilation, and nonspecific vasodilators in treating infants with PPHN, the mortality rate remains unacceptably high (35). Leukotriene inhibition with FPL 57231 may be useful in the management of infants with PPHN and other patients with pulmonary hypertension. The results of this and other studies suggest a significant role for leukotrienes in the perinatal control of pulmonary blood flow and pulmonary vascular resistance and in the mediation of hypoxic pulmonary vasoconstriction.

Acknowledgments. The authors acknowledge Philip Sheard, $\mathrm{MSc}$, of Fisons, plc, Loughborough, UK, for generously providing FPL 57231, and Debby Dewar, R.N., for technical assistance.

\section{REFERENCES}

1. Haas F, Bergofsky EH 1972 Role of the mast cell in the pulmonary pressor response to hypoxia. J Clin Invest 51:3154-3162

2. MacGlashan DW Jr, Schleimer RP, Peters SP, Schulman ES, Adams GK III, Newball HH, Lichtenstein LM 1982 Generation of leukotrienes by purified human lung mast cells. J Clin Invest 70:747-751

3. Rouzer CA, Scott WA, Hamill AL, Cohn ZA 1982 Synthesis of leukotriene C and other arachidonic acid metabolites by mouse pulmonary macrophages. J Exp Med 155:720-733

4. Fleisch JH, Haisch KD, Spaethe SM 1982 Slow-reacting substance of anaphylaxis (SRS-A) release from guinea pig lung parenchyma during antigen- or ionophore-induced contraction. J Pharmacol Exp Ther 221:146-151

5. Piper PJ, Letts LG, Galton SA 1983 Generation of a leukotriene-like substance from porcine vascular and other tissues. Prostaglandins 25:591-599

6. Piper PJ, Seale JP 1978 Release of slow-reacting substance from guinea pig and human lung by calcium ionophore A23187. Br J Pharmacol 63:364P (abstr)

7. Ahmed T, Oliver W Jr 1983 Does slow-reacting substance of anaphylaxis mediate hypoxic pulmonary vasoconstriction? Am Rev Respir Dis 127:566571 
8. Hand JM, Will JA, Buckner CK 1981 Effects of leukotrienes on isolated guinea-pig pulmonary arteries. Eur J Pharmacol 76:439-442

9. Hanna CJ, Bach MK, Pare PD, Schellenberg RR 1981 Slow-reacting substances (leukotrienes) contract human airway and pulmonary vascular smooth muscle in vitro. Nature 290:343-344

10. Schellenberg RR, Foster A 1984 Differential activity of leukotrienes upon human pulmonary vein and artery. Prostaglandins 27:475-481

11. Yokochi K, Olley PM, Sideris E, Hamilton F, Huhtanen D, Coceani F 1982 Leukotriene D4: a potent vasoconstrictor of the pulmonary and systemic circulations in the newborn lamb. In: Samuelsson B, Paoletti R (eds) Leukotrienes and Other Lipoxygenase Products, Raven Press, New York, pp 211-214

12. Sheard P, Holroyde MC, Ghelani AM, Bantick JR, Lee TB 1982 Antagonists of SRS-A and leukotrienes. In: Samuelsson B, Paoletti R (eds) Leukotrienes and Other Lipoxygenase Products. Raven Press, New York, pp 229-235

13. Soifer SJ, Schreiber MD, Loitz RD, Roman C, Heymann MA 1984 The effects of leukotriene inhibition on the perinatal pulmonary circulation in the lamb. In: Jones CT (ed) Physiologic Development of the Fetus and Newborn. Academic Press, London (in press)

14. Stenmark KR, James SL, Voelkel NF, Toews WH, Reeves JT, Murphy RC 1983 Leukotriene C4 and D4 in neonates with hypoxemia and pulmonary hypertension. N Engl J Med 309:77-80

15. Kuipers JRG, Sidi D, Heymann MA, Rudolph AM 1982 Comparison of methods of measuring cardiac output in newborn lambs. Pediatr Res 16:594598

16. Schreiber MD, Heymann MA, Soifer SJ 1984 pH, not PCO2, decreases hypoxic pulmonary vasoconstriction (HPV) in the newborn lamb. Pediatr Res 18:347A (abstr)

17. Zar JH 1974 Biostatistical Analysis. Prentice-Hall, Inc, Englewood Cliffs, NJ, pp $158-173$

18. Fishman AP 1976 Hypoxia on the pulmonary circulation: how and where it acts. Circ Res 38:221-231

19. Blair IA, Dollery CT, Ennis M, Hoult JRS, Robinson C, Waddell KA 1983 Prostaglandin release in pulmonary anaphylaxis: PGD2 a marker of mast cell activation in situ? Br J Pharmacol 78:49P (abstr)

20. Friedman Z, Lunyong VE, Courtney J, Smith H, Berkowitz P, Sun F 1984 Prostaglandin formation in the isolated human ductus arteriosus, aorta, pulmonary and umbilical arteries. Prostaglandins Leukotrienes Med 14:279286

21. Cassin S 1980 Role of prostaglandins and thromboxanes in the control of the pulmonary circulation in the fetus and newborn. Semin Perinatol 4:101107

22. Soifer SJ, Morin FC, Kaslow DC, Heymann MA 1983 The developmenta effects of prostaglandin D2 on the pulmonary and systemic circulations in the newborn lamb. J Dev Physiol 5:237-250

23. Cartwright D, Soifer S, Maurray F, Clyman R 1983 Endotoxin produces acute pulmonary hypertension and thromboxane elevation in the newborn lamb. Pediatr Res 17:306A (abstr)

24. Feuerstein N, Foegh M, Ramwell PW 1981 Leukotrienes C4 and D4 induce prostaglandin and thromboxane release from rat peritoneal macrophages. $\mathrm{Br}$ J Pharmacol 72:389-391

25. Folco G, Hansson G, Grastrom E 1981 Leukotriene C4 stimulates TXA2 formation in isoalted guinea pig lungs. Biochem Pharmacol 30:2491-2493

26. Piper PJ, Samhoun MN 1982 Stimulation of arachidonic acid metabolism and generation of thromboxane A2 by leukotrienes B4, C4, and D4 in guineapig lung in vitro. Br J Pharmacol 77:267-275

27. Seale JP, Piper PJ 1978 Stimulation of arachidonic acid metabolism by human slow-reacting substances. Eur J Pharmacol 52:125-128

28. Welton AF, Hope WC, Tobias LD, Hamilton JG 1981 Inhibition of antigeninduced histamine release and thromboxane synthetase by FPL 55712, a specific SRA-A antagonist? Biochem Pharmacol 30:1378-1382

29. Michelassi F, Landa L, Hill RD, Lowenstein E, Watkins WD, Petkau AJ, Zapol WM 1982 Leukotriene D4: a potent coronary artery vasoconstrictor associated with impaired ventricular contraction. Science 217:841-844

30. Soifer SJ, Loitz R, Roman C, Heymann MA 1984 Do leukotrienes control pulmonary blood flow in the fetal lamb? Pediatr Res 18:347A (abstr)

31. Feddersen OC, Murphy RC, Voelkel NF 1983 Leukotriene E4 causes pulmonary vasodilation which is transformed into vasoconstriction with cyclooxygenase blockade. Fed Proc 42:302 (abstr)

32. Ahmed T, Yerger L, Wanner A, Marchette B 1983 Pulmonary and systemic hemodynamic effects of leukotriene D4 (LTD4): role of leukotriene receptor stimulation and cyclo-oxygenase metabolites. Fed Proc 42:302 (abstr)

33. Morganroth ML, Reeves JT, Murphy RC, Voelkel NF 1984 Leukotriene synthesis and receptor blockers block hypoxic pulmonary vasoconstriction. J Appl Physiol 56:1340-1346

34. Drummond WH, Gregory GA, Heymann MA, Phibbs RH 1981 The independent effects of hyperventilation, tolazoline and dopamine on infants with persistent pulmonary hypertension. J Pediatr 98:603-611

35. Fox WW, Duara S 1983 Persistent pulmonary hypertension in the neonate: diagnosis and management. J Pediatr 103:505-514

\title{
Effect of Infant Age on Aminopyrine Breath Test Results
}

\author{
ROBERT J. SHULMAN, CHARLES S. IRVING, THOMAS W. BOUTTON, WILLIAM W. WONG, \\ BUFORD L. NICHOLS, AND PETER D. KLEIN \\ USDA/ARS Children's Nutrition Research Center, Department of Pediatrics, Baylor College of Medicine, Texas \\ Children's Hospital, Houston, Texas 77030
}

\begin{abstract}
The aminopyrine breath test has been used in adults as a measure of hepatic $\mathrm{N}$-demethylase activity. In order to study maturational changes in enzyme function, ${ }^{13} \mathrm{C}$ aminopyrine $(2 \mathrm{mg} / \mathrm{kg}$ ) was administered orally to infants $(n=16)$ between the ages of 1 and 38 wk. Breath samples were collected for $6 \mathrm{~h}$ after administration of the labeled aminopyrine for the measurement of ${ }^{13} \mathrm{CO}_{2}$ enrichment. Using a number of different scoring methods to

Received August 27, 1984; accepted December 31, 1984.

Address correspondence to Dr. Robert J. Shulman, Section of Nutrition and Gastroenterology, Texas Children's Hospital, 6621 Fannin Street, Houston, TX

This work is a publication of the USDA/ARS Children's Nutrition Research Center, Department of Pediatrics, Baylor College of Medicine, and Texas Children's
\end{abstract} 77030 . Hospital, Houston, TX and is supported by Grant AM28129 from NIAMDDK. quantitate ${ }^{13} \mathrm{CO}_{2}$ elimination of breath, demethylation of aminopyrine was found to be positively correlated to age. By 20 wk of age, some infants had rates of elimination similar to those measured in adults. Absorption was excluded as a limiting variable, because no improvement in oxidation rates was found when the aminopyrine was readministered as an intravenous bolus. Changes in nutritional status and route of feeding (enteral versus parenteral) did not prevent the effect of maturation on aminopyrine elimination. Conclusions: 1) maturational differences are seen in the metabolism of aminopyrine; 2 ) these differences may reflect immaturity of $\mathrm{N}$-demethylase activity or diversion of the liberated formaldehyde into biosynthetic rather than oxidative pathways. (Pediatr Res 19: 441-445, 1985) 